\title{
Industrial architecture in Mieczysław Wolski's factory at ul. 1 Maja 16 in Lublin
}

\author{
Krzysztof Janus \\ https://orcid.org/0000-0002-5391-3140 \\ k.janus@pollub.pl
}

Department of Architecture Urban Planning and Spatial Development, Faculty of Construction and Architecture, Lublin University of Technology

\section{Karol Krupa \\ https://orcid.org/0000-0002-7313-4080 \\ k.krupa@pollub.pl}

Department of Contemporary Architecture, Faculty of Construction and Architecture, Lublin University of Technology

\begin{abstract}
The paper presents the architectural development of the former M. Wolski i s-ka factory in Lublin from the period before its establishment, through its heyday, until the collapse, which took place after the change of the political system. Its historical outline has also been presented, together with the circumstances of its establishment, most important events connected with its development or collapses. Designs of subsequent facilities were used for the purposes of the present paper, found in the collections of the National Archives in Lublin.
\end{abstract}

Keywords: Wolski i s-ka Agricultural Machines Factory, Mieczysław Wolski, ul. 1 Maja 16 in Lublin, Piaski suburb

\section{Introduction}

Before the establishment of the factory, this area consisted of farm buildings and jurydyki, and later the village of Piaski-Kazimierz. Jurydyka had been functioning in the $18^{\text {th }}$ century and it was inhabited mainly by the Jewish community [1]. This is how S.Z. Sierpiński described the suburb in 1819 "Kazimierz, Przedmieście, today improperly called Jewish Piaski; as in past documents and on the map it was named Kazimierz, it is located by the Bystrzyca River on the opposite side of the meadows, incorporated into the market square and a few streets with miserable wooden houses, on sandy soil. This is where the criminals are executed" [2].

In 1783, in place of the discussed property, several agricultural farms were located, assuredly with wooden huts and farm buildings situated along the road, the course of which was similar to the current 1 Maja Street.

The area experienced its greatest development in the $19^{\text {th }}$ century, when the railway reached Lublin and direct connection of the station with Lublin led through 1 Maja Street. The short distance from the station and the main communication road resulted in agricultural areas being quickly replaced with industrial zones or residential areas.

\section{History of the factory}

First mentions of the factory date back to 1875 , when basing on the act as of September $25^{\text {th }} /$ October $7^{\text {th }}$ for the total amount of 279 rubles and 10 kopeks (including 69 rubles and 7.5 kopeks transferred to the Governorate 
Fund in Lublin and 74 rubles 42.5 kopeks for the intended for the repayment of mortgage [3]) "the Factory of Agricultural Machines and Tools under the name Mieczysław Wolski i Współka purchased via double purchase and sale act from the Treasury of the Kingdom from Karol Ciechowski's successors via bidding by the intermediary of the Treasury of the Kingdom [4]". In 1875, Mieczysław Wolski (factory owner from "Nowa Aleksandria") together with Mieczysław Łabędzki (owner of the Prusy Górne properties and other in the Radom Governorate) purchased the properties under the numbers 6/7 in the Piaski suburb in Lublin [5]. The properties had a surface of 53795 square ells1. Soon after, on November 1 15t, 1875, they formalized the creation of the "Mieczysław Wolski i spółka" company, established for a period of ten years [6]. Basing on the arrangements written under the form of agreement, Mieczysław Wolski was supposed to become the head of the factory with the right to receive and employ staff and artisans; he was also responsible for appropriately equipping the factory and managing it, while the modification of the size of the factory, or its principal manager, was subject to the approval by both partners. Wolski was also supposed to assume the responsibility for the purchase of materials, the sale of ready-made goods, he could issue bills of exchange up to the amount of 300 rubles. Both partners contributed to covering company capital with the amount of 2000 rubles in cash. Additionally, Mieczysław Łabędzki lent to the company a sum of 20000 rubles (with an annual interest rate of $7 \%$ ). The administrator was additionally supposed to receive 400 rubles of annual salary. An iron foundry was planned in the factory, with a "fire" stove and "locomotive". The administrator could purchase agricultural machines from other factories or "take them in commission" [7]. The construction had to progress fast, as already in October 1875 fire assessment was performed for the facility, which proves that, at that time, the factory was completely, or largely, finished. The assessment included five objects:

1. The building, including the factory of agricultural machines and tools, with a brick and mortar structure, covered with an iron sheet with outbuildings.

2. Shingled timber building.

3. Shed on timber posts, shingled.

4. Shed on timber posts, shingled.

5. Wooden fencing with a reinforced gate with a length of $550 \mathrm{~m}$ and a height of $4.5 \mathrm{~m}$.

All buildings were estimated for the amount of 14470 rubles (including the factory building for the amount of 13450 rubles) [8]. Steam machine had already been installed in the outbuilding (with the value of 2100 rubles), a boiler room and other equipment which prove that the factory was ready to start functioning or it was already in operation. The main products sold by the company were horse mills, chaff cutters, threshers, winnowing machines and iron casts, mainly exported to Russia [9].

Two years later, a shed with the dimensions of $44 \times 10$ meters was erected [10]. From that time, the period of successive and continuous extension began, proving that the factory was in good condition, which lasted until the interwar period. However, it consisted in majority of one-level brick and mortar or mainly timber buildings. The first big investment project after the establishment of the factory was its planned extension from 1880. A residential building was supposed to be constructed then, connected with a warehouse as well as a foundry.

In 1893, the extension of the building erected in 1875 for the purposes of installation of two robust coal cauldrons took place [11]. In 1895, J. Junczys performed the design for the construction of an outbuilding, including two casting stoves, equipped with two characteristic chimneys and an internal steel structure. The building was not preserved until present times.

Mieczysław Łabędzki died in 1903 and Mieczysław Wolski a year later. This was also the time when the factory began to experience its first problems, both of a financial character as well as connected with the demand for its products. The situation improved thanks to Aleksander Hafner, who led the factory out of stagnation and began to invest. He was the initiator of the process of reconstruction of timber buildings into brick and mortar ones. The only presentation of the factory performed for advertising purposes (probably on the occasion of one of agricultural exhibitions) comes from this period. In 1913, the facility consisted of a total of 35 buildings [12].

In 1918, the design for the performance of the main driving gear in the machine room, performed by "Poręba" Shares Association of Miners, Iron Casts, Mechanical Workshops and Coal Mines, was prepared. In 1926, the 
facility received power thanks to a steam machine with a generator of three-phase current, 220/380V, 220HP (min $200 \mathrm{HP}, \max 250 \mathrm{HP}$ ) [13].

In the interwar period, the entire yard was paved, while narrow-gauge railway pulled by horses or pushed by the workers was used for transporting heavy loads. The railway tracks were connected with one another at right angles, and thanks to turntables located in characteristic points, it was possible to rotate the wagon/cart and change its direction. The system was used already at the beginning of the $20^{\text {th }}$ century and remained in operation until at least the Second World War. Its tangible traces were not preserved, but the railway system is visible on historical plans, drawings and photographs.

In 1921, the Joint-Stock Company M. Wolski i S-ka Factory of Agricultural Machines and Tools in Lublin was established. In the same year, for the amount of 2.834 million marks, it purchased from Stanisława Wolska, Maria Łabędzka and Henryk Jasiński $3 / 4$ of the shares of the newly established company [14]. It purchased the remaining $1 / 4$ of shares in 1922 for the price of 945 thousand marks from Izabela Wolska ${ }^{2}$. During the establishment of the company, Stanisława Wolska obtained 5740 shares, Maria Wolska 3750 shares, Maria Łabędzka 4750 shares, Henryk Jasiński 4790 shares, Ludwik Hafner 200 shares and 15 other people. In total, they received 20000 shares with a value of 1000 marks each [15].

The factory was constantly developing, and in the years 1926-27, two branches of the plant were established in Zamość, Hrubieszów together with the department in Lviv [16]. The offer of the factory included equipment considered modern at that time: French spiked harrows, spring cultivators, Jordan's markers and ribbing ploughs, ring rollers, Campbell's compactors, mills with a power ranging from one to ten horses, horse mill attachments, threshers, winnowing machines, "tryumf" winnowers with or without sieves, drum, mill and hand ax cutters [17]. In the years 1935-37, the factory also launched the manufacturing of bodies for buses, ambulances, together with wooden household appliances as well as bullets and grenade shells for the army [18].

In the interwar period, the financial condition of the facility deteriorated importantly. On December $22^{\text {nd }}$, 1931, the first factory auction was organized [19]. At that time, debt amounted to ca. 1.4 million zlotys and 25 thousand dollars (including about 280 thousand zlotys of tax arrears) [20]. Finally, the factory went bankrupt after a long time, and in 1939, it was leased by Marian Sowa Mechanical Plant with the right for the use of trademarks [21].

In the years 1939-44, the factory operated under German management and produced for the purposes of the German army. But not every product leaving the factory was premium quality. The workers would undercut transmission belts, perform short circuits in electrical devices, etc. [22]. The factory bathroom constituted a meeting point for the Poles sent to forced labor in Germany, where the employees would often dress them in workers' uniforms and lead out of the facility [23].

After the war, both factory workers as well as its lessees came back, but already in 1947, basing on the ordinance of the Minister of Industry and Commerce as of June $24^{\text {th }}, 1947$, the State Treasury became the owner of the factory [24]. Its name was changed into the 1905 Revolution's Lublin Agricultural Machines Factory.

Further history of the factory facilities remains not clearly known. After 1950, the entire factory was subject to thorough modernization, and its capacity was increasing very rapidly. Its importance began to decrease after 1968, when the construction of a manufacturing facility in Wrotków began. The plant would then frequently change its name, but it was still the agricultural machines plant. We did not manage to find a lot of information concerning the transformation, which took place within that period, but it can be said with confidence that these changes concerned mainly the manufacturing process, i.e. the introduction of new technologies. The majority of buildings (apart from the boiler room and carpenter's workshop) preserved their initial look and character. After the collapse of the factory, the property was divided into 16 plots, and currently, activities of a varied nature are conducted in subsequent buildings or their parts: from a bank, through grocery stores, glassmaking workshop or a cheap clothes store, right up to a hotel.

2 Total amount of 3779 million marks for which the factory was purchased seems surprisingly low taking into consideratin the vast area of this industrial district of Lublin, where several dozen factory buildings could be found together with their equipment - in 1921, Stanisława Wolska purchased the building of the Uciecha villa in Nałęczów for 6 million marks, the property consisting of ca. 1.5 hectares and 3 buildings. 


\section{Buildings}

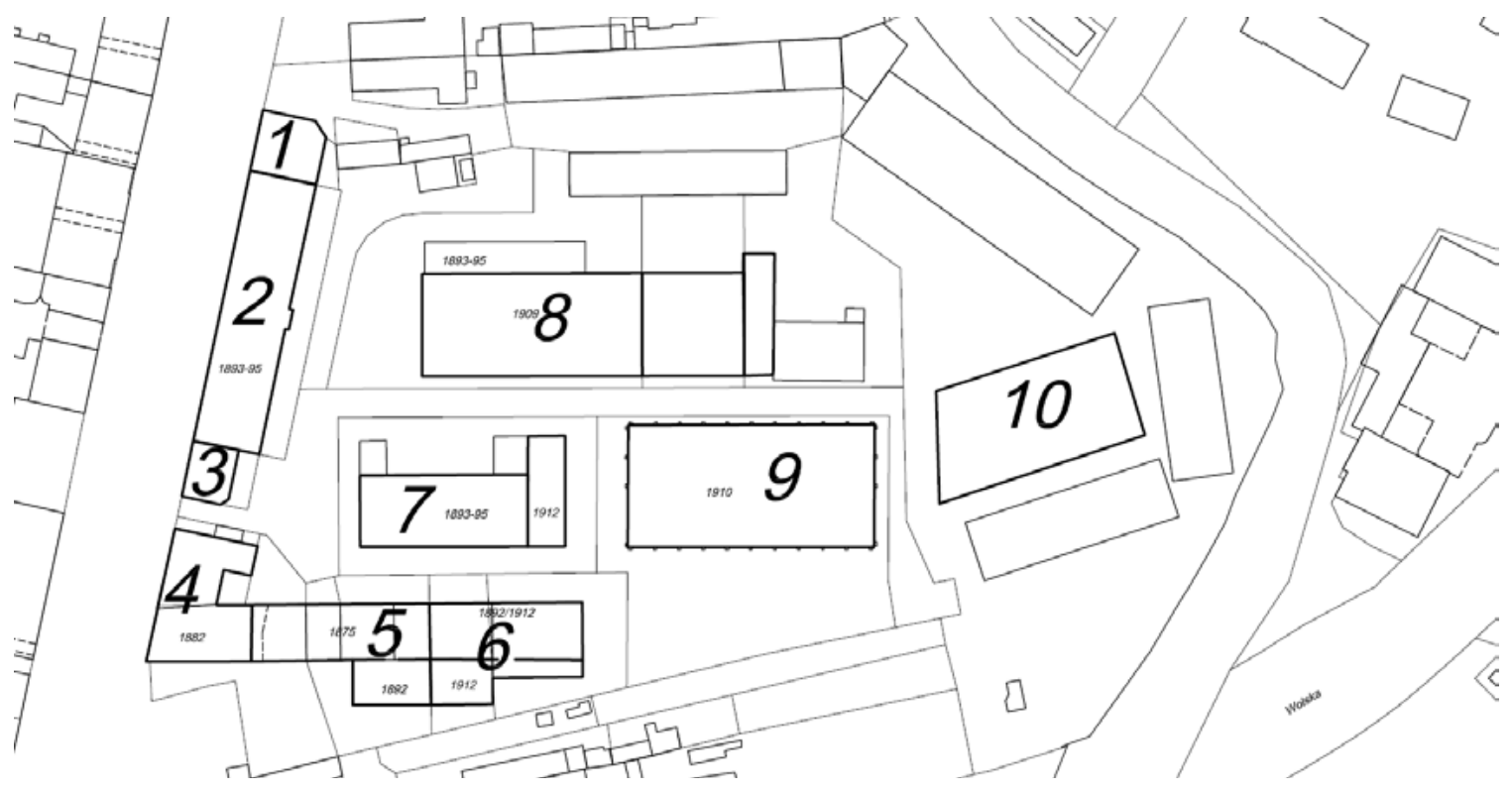

Fig. 1. Former Wolski factory complex. 1 - Exhibition pavilion, 2 - Warehouse, 3 - Reception, 4 - Office and apartment building, 5 - The first factory, 6 - Boiler room with machine room, 7 - Smithy, 8 - Foundry, 9 - Carpenter's workshop, 10 - Installation room

1. Exhibition pavilion within plot number 14. Its construction design was not signed by the author; it only includes the date "4/IV 1914" [25]. What is interesting is that it was described in Polish with the scale expressed in Polish ells ${ }^{3}$. According to the design, the interior was supposed to consist of one space with two steel posts on which a timber ceiling had been supported. After the Second World War, it was divided into two levels and additional rectangular openings were performed, inconsistent with the façade. In 1993, the pavilion was deprived of its roof, with the risk of collapsing. In the early $20^{\text {th }}$ century, it underwent reconstruction and was extended upwards. Nowadays, it hosts a bank.

2. Warehouse building. It was erected in the years $1893-95$ as a three-level warehouse object covered with roofing felt. Jan Junczys was the author of its design [26]. He designed the building with a porch in its axis, including a staircase and one room on its both sides, with a line of timber posts in its middle. The building was damaged during WW2, when its ceilings and the roof were destroyed [27]. It underwent numerous reconstructions and transformations to serve different functions. Currently, a bank is located in it, and in the past there used to be a hotel.

3. The reception building dates back to the late $19^{\text {th }}$ century. Most probably at the beginning of the $20^{\text {th }}$ century, one more level was added, and the next level - the third one - was constructed in the 1990s.

4. Residential and office outbuilding. It was erected in 1882, when once again, J. Junczys performed the design of a two-level office and residential building (with the function of an unrealized building from 1880). It was connected with the factory building constructed in 1875. After WW2, a factory school was located there, together with workshops, offices and a hotel [28]. It practically did not change its form since the period of its establishment.

5. The first factory. On March $21^{\text {st }}, 1875$, Mieczysław Wolski applied to the Lublin City Hall for building permission for the construction of an agricultural machines factory, including a steam machine [29]. Aleksander Zwierzchowski was the author of the design, which assumed the performance of a building consisting of two interconnected parts (one of them with a single level and the second with two levels). In the two-level part, the space for the foundry and smithy was reserved, while on the ground floor of 
the two-level section, a big ironworks area with a width of ca. 11 meters and four round (most probably iron) posts in the middle. This section included also the counting room and a technical back-up office. The upper level was supposed to include one space with four posts, repeating the ground floor arrangement. The access to it was ensured by external stairs. The building underwent numerous transformations, reconstructions and extensions and its function would also change, but it was preserved until today in a nearly unaltered form. Until recently, the stairs functioned in their initial location, but only their negative was preserved.

6. Boiler room with machine room. The first buildings were erected in place of today's machine room in 1880 in order to prolong and extend the existing factory with an additional foundry area, designed by Jan Junczys [30]. The established building in its ground floor form with gable roof constituted some kind of prolongation of the already existing ground floor performed after the year 1875 . The boiler room did not include inside divisions or a ceiling. It was connected with the existing building by means of additional wide passages performed in the place of windows. The façade followed the characteristics of the already existing buildings. Later, the building underwent several reconstructions, with outbuildings serving different purposes added to it; the majority of them were not preserved until today. In 1912, a design for the reconstruction of the foundry building into a boiler room and machine room was developed. During its reconstruction (similarly to other cases), the existing building was demolished and replaced with a new one. When it comes to the building containing the machine room, internal partitions were removed without changing its outline. A steam machine that took up nearly the entire space was designed, together with performing the flooring with terracotta tiles ${ }^{4}$. Roof structure rails with transverse timber rafters extending beyond external walls were supported on four steel girders. As far as the building containing the boiler room is concerned, its interior consisted of one space and the roof was supported on two steel trusses. Entrances were designed in the eastern spans of the side façades (only one was performed). Both buildings were given the same height and the same façade decoration (brick with plastered encircles). Until 1912, both buildings formed an inseparable structure (steam was produced in one of them, and in the second, it was transformed into mechanical and electrical energy). Such a situation persisted until the performance of electrical connection from municipal power house. The machine room persisted in a practically unaltered form until today and its renovation and conservation may constitute a model for performing renovations in industrial buildings. When it comes to the machine room, it is not completely certain, but around 1963, the object was extended upwards and importantly modernized. The façades were plastered, and apart from the remnants of pilasters, it is impossible to notice the primary architectural features of the building. It is almost the only one of the buildings within the facility deprived of historical traces.

7. Smithy. The building was erected between 1893 and 1895 in a form consisting of a ground floor with a gabled roof finished with a skylight. In 1912, an outbuilding, supposed to serve the function of a wood drying room, was added to it from the eastern side.

8. Foundry. The most characteristic of all factory buildings, designed in $1909^{5}$. It was performed very fast with small differences compared to the design [31]. A concept for the extension of the object with a hall with a surface of $1000 \mathrm{~m}^{2}$ was developed in 1928. However, the surface of the added hall was actually two times smaller and it referred to the existing developments and façade arrangement. Nowadays, the building hosts a glazing workshop.

9. Carpenter's workshop. The building was erected in 1910 to serve as a workshop [32]. It was divided into two parts - one consisting of a single space from the south and a two-level from the north. The older timber building was demolished during its construction. It was the second object after the boiler room (but to a significantly lower extent) to undergo reconstruction, making it lose it stylistic features. The arched windows of the southern façade were removed, replaced with two levels of rectangular windows, the interior was divided by an additional level and the façade was deprived of its detail and plastered. In 2003, the object was renovated and transformed into a shopping center.

4 Part of the flooring was preserved until today and what is more, thanks to its complementing it can be specified where subsequent parts of the machine were situated.

5 Only one person signed the design - Ludwik Hafner, Director of the factory. 
10. Installation room. The building was erected in 1928. It was designed as an asymmetrical hall with the interior consisting of one space. It was realized a year later, but with important modifications compared to the design. Its capacity, dimensions and outline were preserved, but the façade was performed in reference to the existing objects. Window openings were transformed from closed flat into arched and sectional ones and the façade gained a brick character with plastered encircles, cornices and pinnacles.

\section{Photographs and figures}

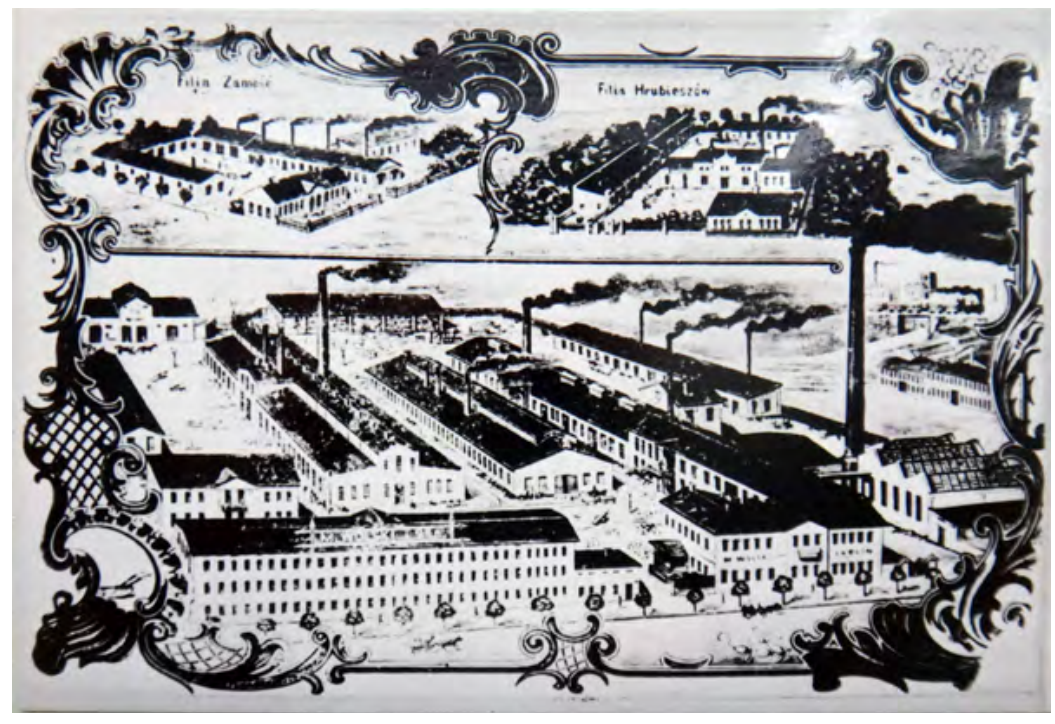

Fig. 2. View of the Wolski factory before 1912, Archives of Lublin Voivodeship Monuments Conservator, photo card, sign. 11549

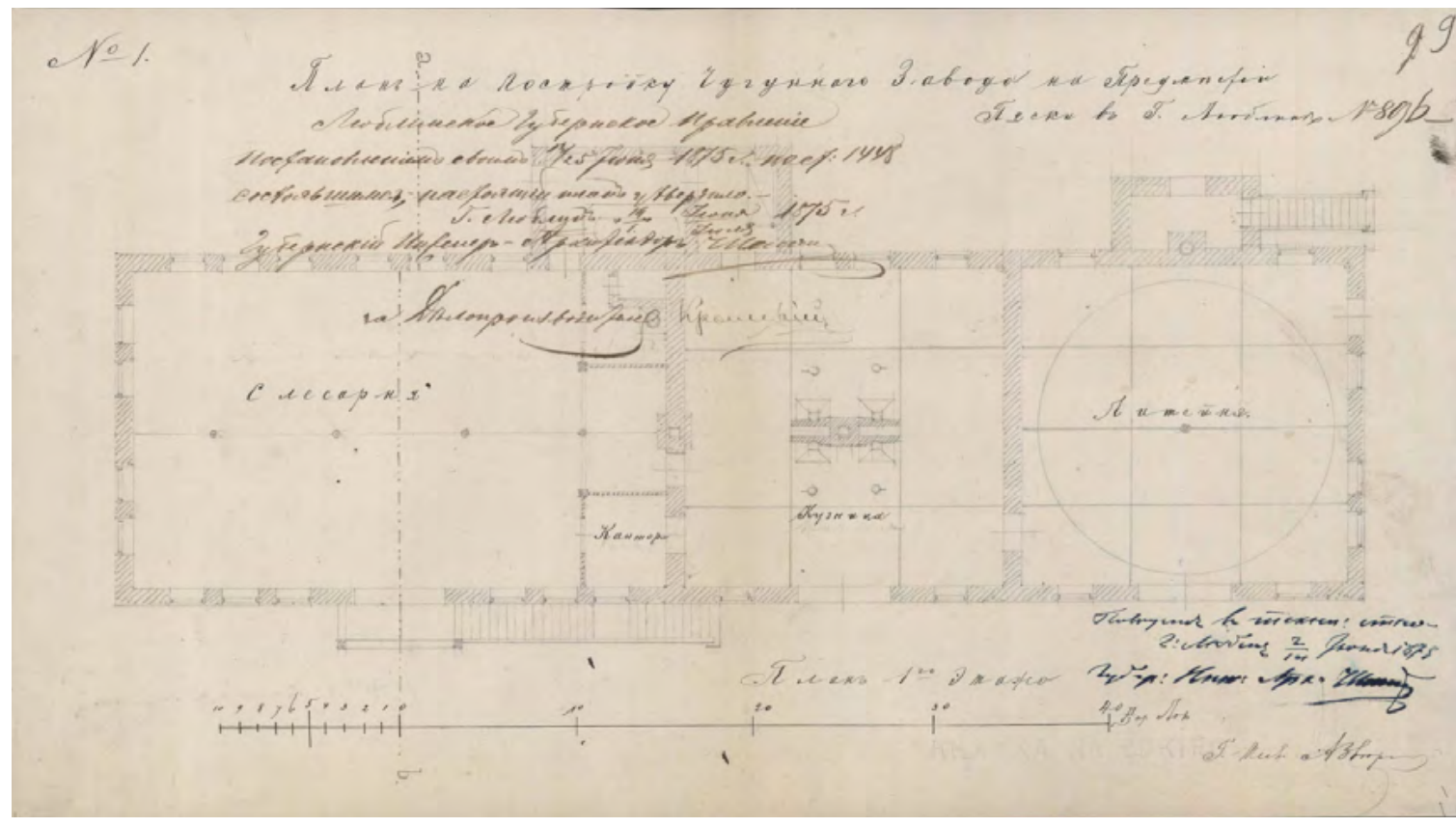

Fig. 3. Design of the factory from 1875 - Ground floor plan, National Archives in Lublin, Lublin Governorate Government, Construction I, sign. 1875:29 


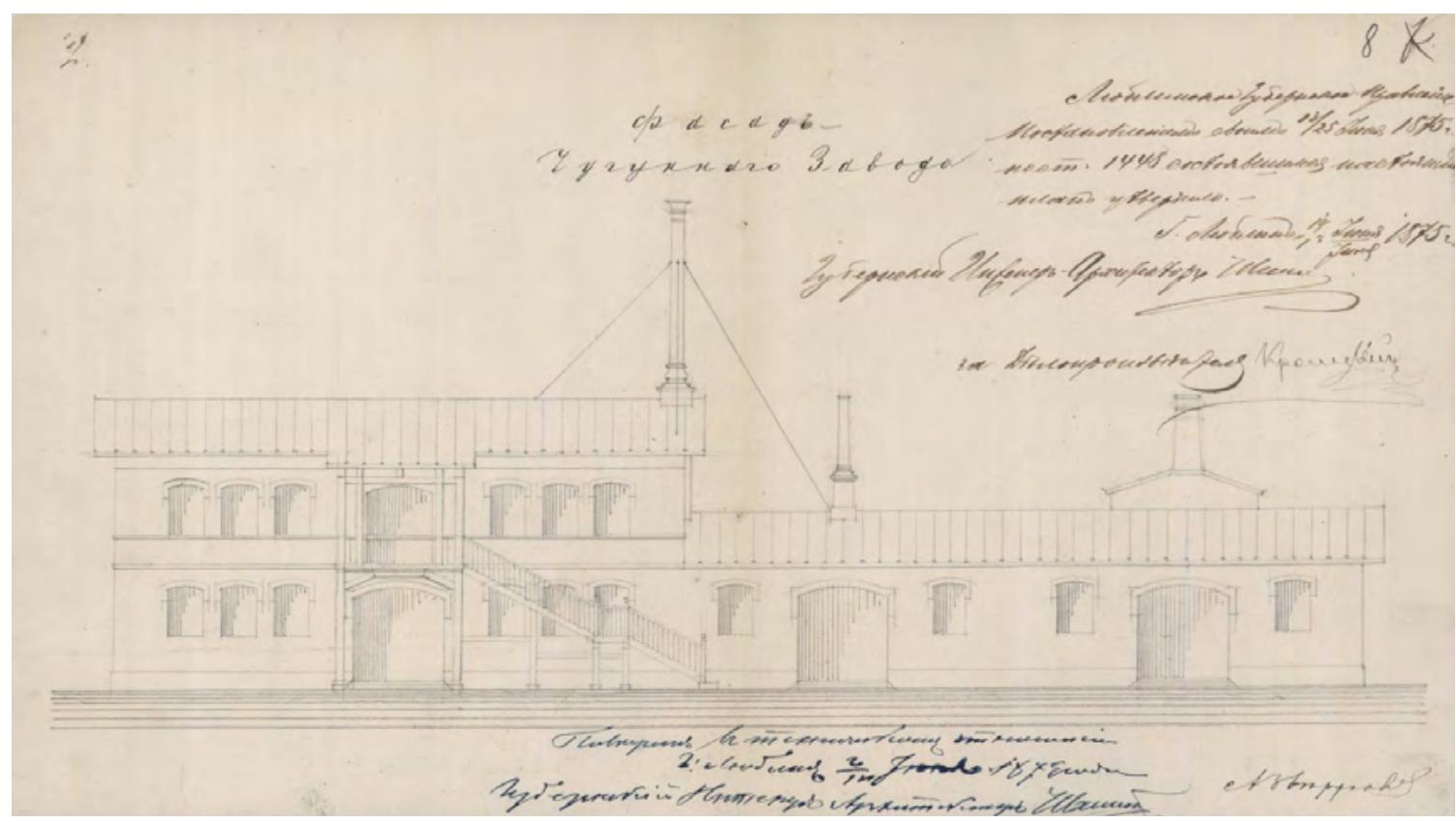

Fig. 4. Design of the factory from 1875 - façade, National Archives in Lublin, Lublin Governorate Government, Construction I, sign. 1875:29
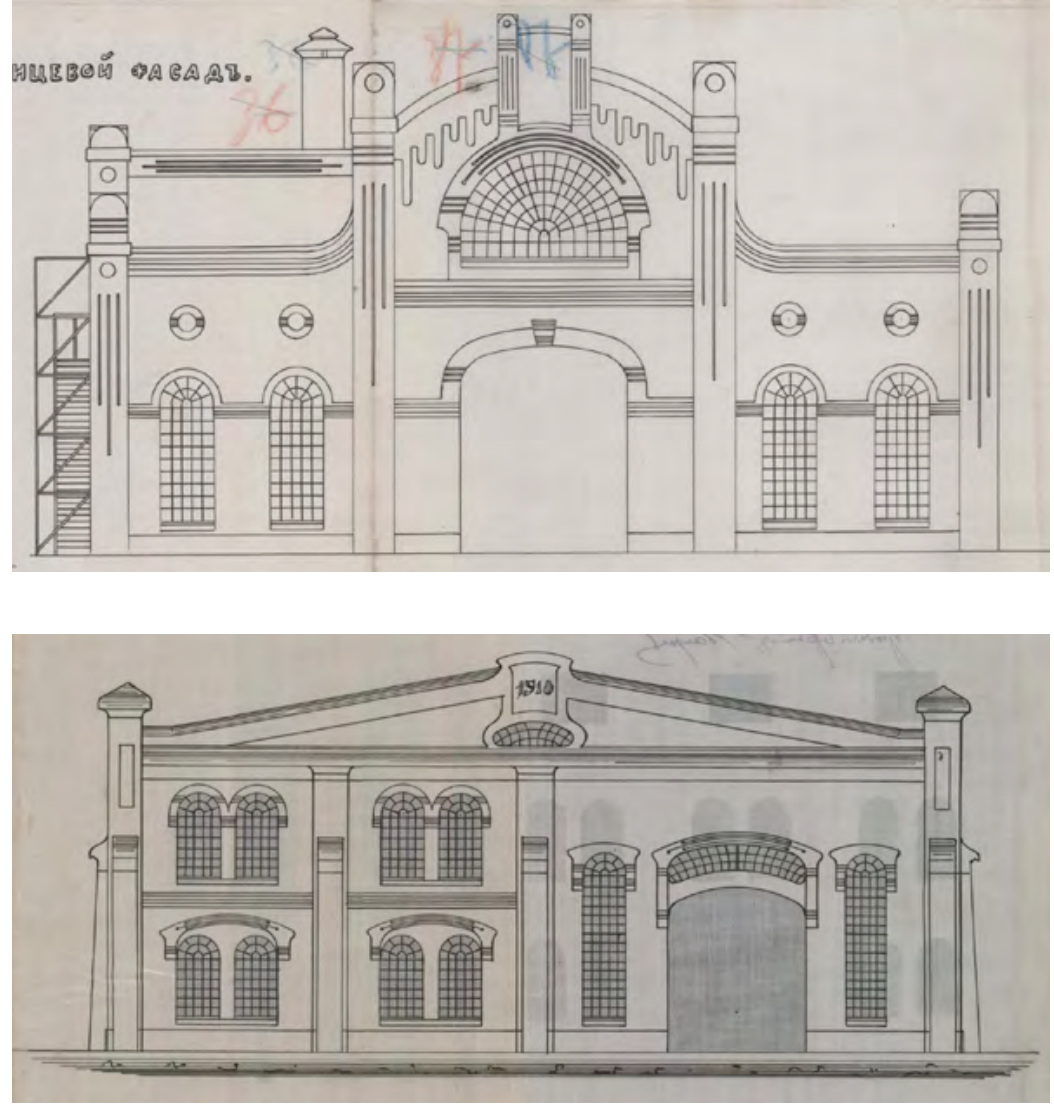

Fig. 5. Design of the foundry building - front façade - 1909, National Archives in Lublin, Lublin Governorate Government, Construction I, sign. 1909:4 part 1 p. 34

Fig. 6. Design of the carpenter's workshop building - front façade - 1910, National Archives in Lublin, Lublin Governorate Government, Construction I, sign. 1910:4, p. 294 

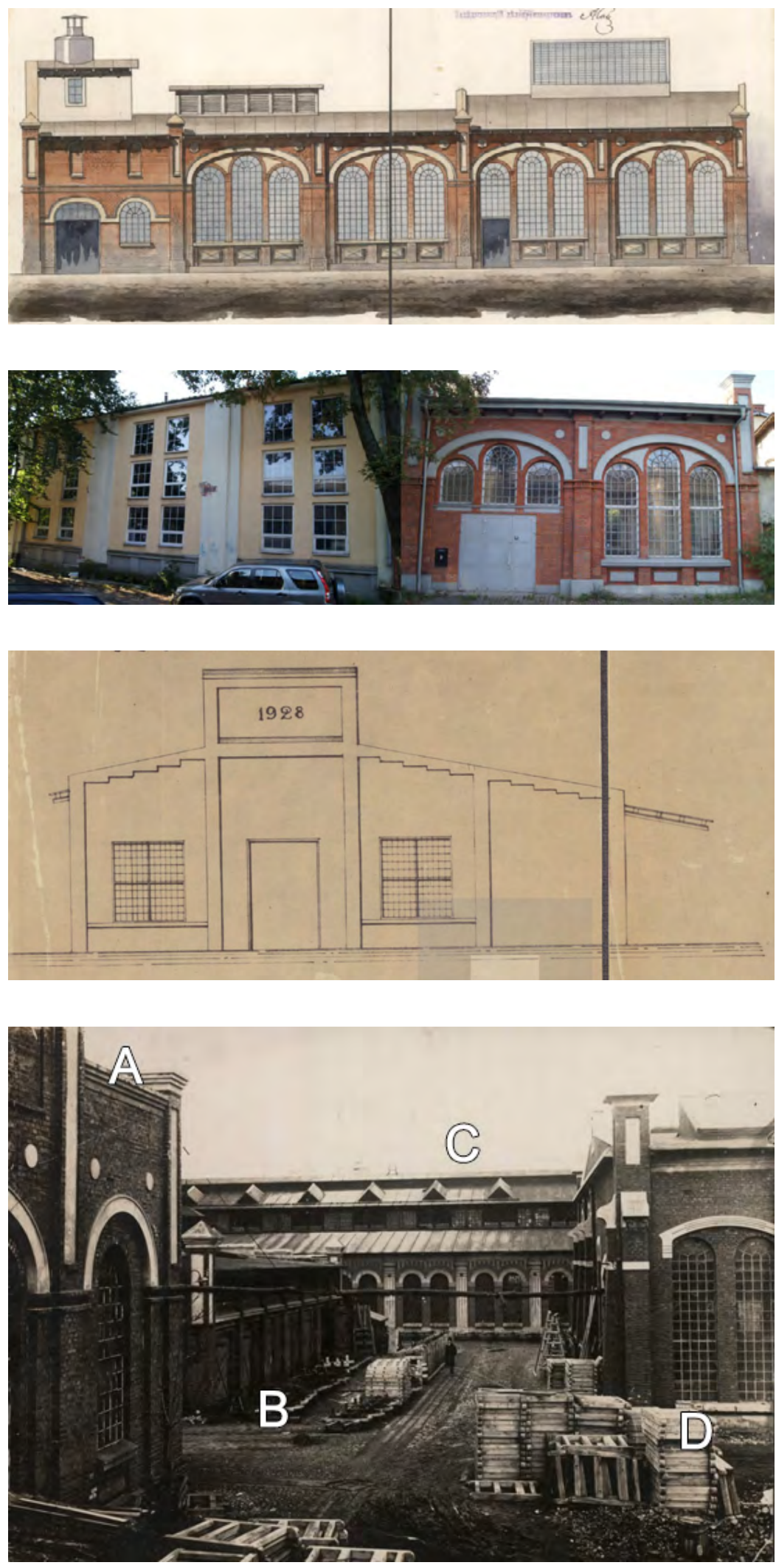

Fig. 7. Design of the boiler room and machine room building, 1912 - Front façade, National Archives in Lublin, Lublin Governorate Government, Construction I, sign. 1385 , p. 4, 5

Fig. 8. Building of the boiler room and machine room - shot from 1912 repeated (Fig. 7)

Fig. 9. Design of the installation room - front façade - 1928, National Archives in Lublin, Lublin Voivodeship Office, sign. 1448

Fig. 10. Fragment of the front façade of the machine room building, 1928, National Archives in Lublin, JointStock Company M. Wolski i S-ka Factory of Agricultural Machines and Tools in Lublin, sign. 278 photo 9 , ( $A$ - boiler room, $B$-drying room, $C$ foundry, D - carpenter's workshop) 

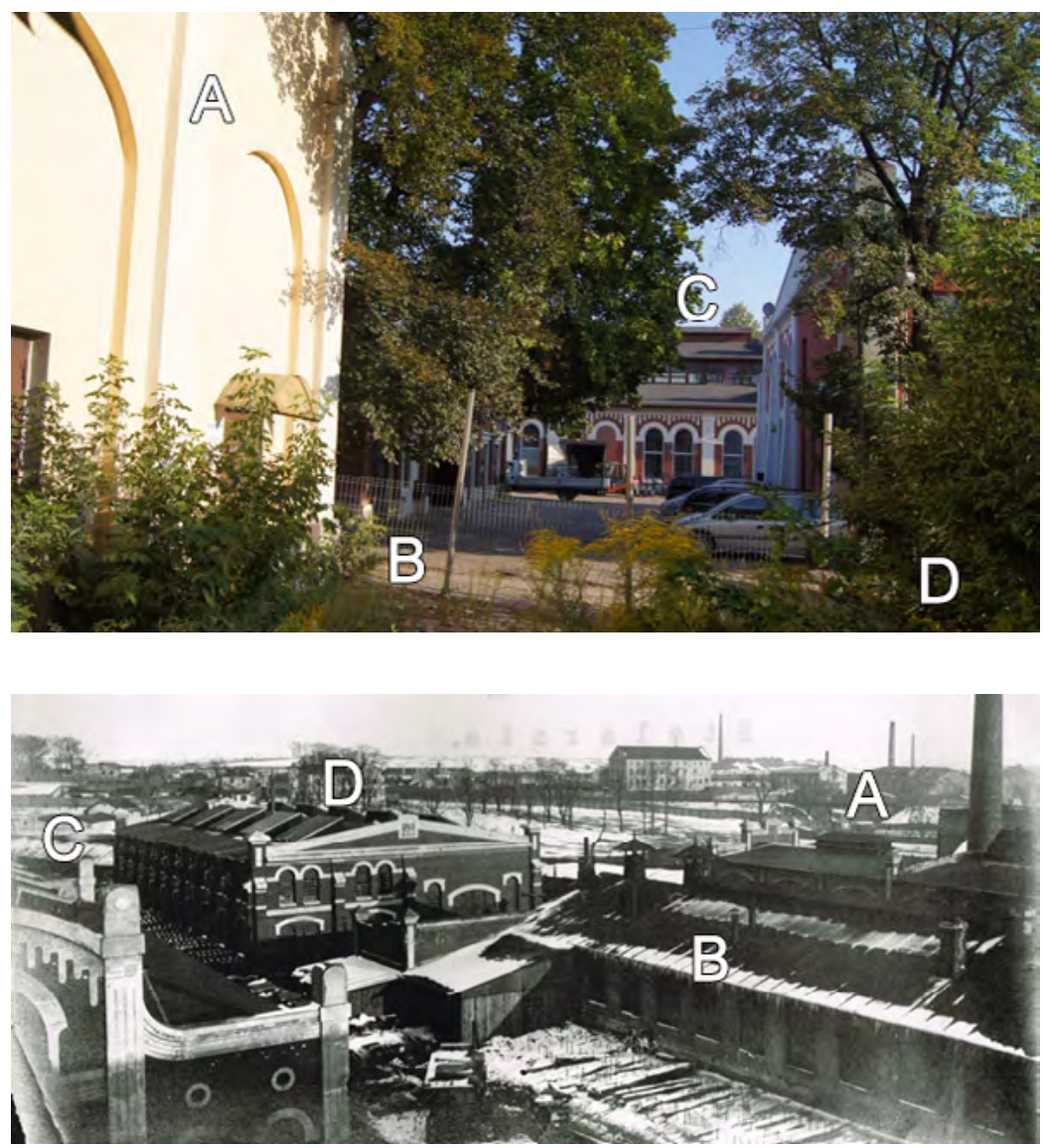

Fig. 11. Fragment of the front façade of the machine room building - an attempt to repeat the shot from Fig. 10, (A - boiler room, B - drying room, C - foundry, D - carpenter's workshop)

Fig. 12. Fragment of the photograph presenting arched spans of the boiler room and machine room building, ca. 1929, Archives of Lublin Voivodeship Monuments Conservator, photo cards, sign. 27568, (A - boiler room, B - smithy, C - foundry, D - carpenter's workshop)

\section{Conclusions}

The Agricultural Machines Factory was erected from scratch in 1875 within the newly established and rapidly developing district of Lublin. The short distance to the newly constructed railway station as well as a location next to the road connecting Lublin with the station made the communication and development of the factory significantly easier. The current picture is unfortunately totally opposite, as industrial activity has left this area and the neighborhood does not enjoy good reputation, and is not too safe either, which does not encourage potential investors or citizens to visit it. The factory facilities had their ups and downs, experienced wars and fires, changes of owners and political systems, frequent transformations and modifications of the technological process, but they have preserved large quantities of the very valuable (even if relatively young) historical substance. The architecture had its heyday in the years 1909-1914, when Ludwik Hafner became the factory manager after the death of its owners. This is when the following facilities were established: exhibition pavilion, boiler room with machine room, smithy, foundry and carpenter's workshop. These buildings were characterized by a specific combination of brick and plaster on the façade, which was repeated in the extensions and new buildings until 1928. In spite of their industrial character (which resulted in frequent changes of the manufacturing process, introducing new functions or technologies), the buildings, apart from the boiler room and carpenter's workshop, were preserved relatively unmodified until today, preserving their specific character. The property intended for factory purposes in 1875 has currently been divided into 16 independent plots of different sizes and varying purposes. Smaller and bigger shops are situated here, together with offices, workshops or banks. Subsequent buildings were preserved to a certain extent. Some of them were renovated to serve as a model (machine room building) and others are waiting for renovation and having their initial look and character restored, often changing their function and owners. In spite of a large surface exceeding $1000 \mathrm{~m}^{2}$, accessible parking spaces do not attract investors or users who would be able to revitalize them. 


\section{Bibliografia}

[1] N. Przesmycka, Lublin. Przeobrażenia urbanistyczne 1815-1939 (Lublin. Urban transformations 1815-1939), Lublin 2012, p. 127.

[2] Z. Sierpiński, Obraz miasta Lublina (Image of the city of Lublin), Warszawa 1839, p. 31.

[3] Archives of the $10^{\text {th }}$ Land Registry of the Lublin-Zachód District Court in Lublin, Mortgage Register 690, p. 454.

[4] Ibid., p. 6.

[5] Ibid., p. 483.

[6] Archives of the $10^{\text {th }} \ldots$, op. cit., p. 484.

[7] Archives of the $10^{\text {th }} \ldots$, op. cit., p. 500.

[8] National Archives in Lublin, Records for the city of Lublin 1809-1874, sign. 8001 assessment as of 10/22 October 1875.

[9] M. Denys, Zanim powstała SPIMA S.A. (Before SPIMA S.A. was established), Na Przykład magazine, no 29, 1995, p. 3.

[10] National Archives in Lublin, Archives of the city of Lublin 1809-1874, sign. 8001.

[11] National Archives in Lublin, Lublin Governorate Government, Department of Architecture, Construction I, sign. $1893: 4$.

[12] Archives of the $10^{\text {th }} \ldots$, op. cit., p. 5 .

[13] National Archives in Lublin, Joint-Stock Company M. Wolski i S-ka Factory of Agricultural Machines and Tools in Lublin, sign. 150.

[14] Archives of the $10^{\text {th }} \ldots$, op. cit., p. 8 .

[15] Archives of the $10^{\text {th }} \ldots$, op. cit., p. 660.

[16] M. Denys, op. cit., p. 3.

[17] M. Denys, op. cit., p. 3.

[18] M. Denys, op. cit., p. 4.

[19] Archives of the $10^{\text {th }} \ldots$, op. cit., p. 719.

[20] Ibid., p. 726.

[21] M. Denys, op. cit., p. 4.

[22] Ibid., p. 4.

[23] Ibid., p. 4.

[24] Archives of the $10^{\text {th }} \ldots$, op. cit., p. 9.

[25] National Archives in Lublin, Joint-Stock Company..., op. cit., sign. 262.

[26] National Archives in Lublin, Joint-Stock Company..., op. cit., sign. 262.

[27] Monument record card, Archives of the Voivodeship Monuments Conservator in Lublin.

[28] Ibid.

[29] National Archives in Lublin, Lublin Governorate Government, Construction I, sign. 1875:29.

[30] National Archives in Lublin, Lublin Governorate Government, Construction I, sign. 1880:2.

[31] National Archives in Lublin, Lublin Governorate Government, Construction I, sign. 1909:4 part 1, p. 36-40.

[32] National Archives in Lublin, Lublin Governorate Government, Construction I, sign. 1910:4, p. 294. 